\title{
Intermittent lighting programs for layers with different photophases in the beginning of the laying phase
}

\author{
Programas de iluminação intermitentes para poedeiras com \\ diferentes fotofases ao início da fase de postura
}

\author{
Flavio Manabu Yuri ${ }^{\mathrm{I}}$ Cleverson de Souza ${ }^{\mathrm{I}}$ \\ Aline Felix Schneider ${ }^{I}$ Clóvis Eliseu Gewehr ${ }^{I}$
}

\begin{abstract}
It was possible to evaluate the effect of continuous and intermittent lighting programs with different photophases on the performance and eggs quality of laying hens, applied to the beginning of the laying phase. The authors used $420 \mathrm{Hy}$-line Brown laying hens with 21 weeks of age, bred on bedding and submitted for six periods of 28 days between the solstice of summer and winter. The three lighting programs were: (PIC) 16 hours of continuos light, intermittent program with initial and final photophases of 15 minutes (PII15) and an intermittent program with initial and final photophases of 30 minutes (PII30). A completely randomized design with ten repetitions of 14 birds was used. The mean values were subjected analysis of variance and analyzed by the Tukey test (5\%). The PIC program showed higher feed intake and eggs' mass about the PIII5, and the eggs production of birds, in the PIC, was $1.8 \%$ greater than the intermittent photoperiods. Programs of light did not change the egg quality. The intermittent programs for semiheavy laying hens bred on bedding in an open shed, applied at the beginning of the laying phase, reduced the productive performance of the birds without affecting the eggs quality.
\end{abstract}

Key words: scotoperiod, photophase, photoperiod, hens.

RESUMO

Avaliou-se o efeito de programas de iluminação contínuo $e$ intermitentes com diferentes fotofases sobre o desempenho produtivo e a qualidade de ovos de poedeiras aplicados ao início da fase de postura. Foram utilizadas 420 poedeiras da linhagem Hy line Brown com 21 semanas de idade, criadas sobre cama, submetidas durante seis periodos de 28 dias, entre o solstício de verão e de inverno, a três programas de iluminação: contínuo (PIC) de $16 \mathrm{~h}$ de luz; programa intermitente com fotofases inicial e final de 15min (PII15); e programa intermitente com fotofases inicial e final de 30min (PII30).
Utilizou-se um delineamento inteiramente casualisado, com dez repetições de 14 aves. Os resultados das médias foram submetidos à análise de variância e analisadas pelo teste de Tukey (5\%). O programa PIC apresentou maior consumo de ração e massa de ovos em relação ao PII15, a produção de ovos das aves no PIC foi $1,8 \%$ superior aos fotoperiodos intermitentes. Os programas de luz não alteraram a qualidade de ovo. Programas intermitentes para poedeiras semipesadas, criadas sobre cama em galpão aberto, aplicados no inicio da fase de postura reduzem o desempenho produtivo das aves sem afetar a qualidade de ovos.

Palavras-chave: escotoperiodo, fotofase, fotoperiodo, galinhas.

\section{INTRODUCTION}

The studies on lighting programs for laying hens are conducted from the beginning of the poultry industry, and the results are evident in the stimulation of the reproductive tract. The combination of artificial light and natural photoperiod enables the development of lighting programs to increase the egg production (FREITAS OLIVEIRA \& GEWEHR, 2010), and it is considered an essential management tool in commercial laying poultry (COENEN et al., 1988; ER et al., 2007).

Currently, in open sheds, lighting programs are used to provide between 15 and 16 hours of uninterrupted light preceded by eight to nine hours dark (GEWEHR et al., 2012). They are called continuous programs (GEWEHR \& FREITAS, 2007). Among some alternatives to reduce the energy cost to

IUniversidade do Estado de Santa Catarina (UDESC), Avenida Luiz de Camões, Bairro Conta Dinheiro, 88520-000, Lages, SC, Brasil.

E-mail: cleversonsz@hotmail.com. *Corresponding author. Received 03.08.16 Approved 06.16.16 Returned by the author 09.12.16 CR-2016-0246.R1 
illuminate the sheds, it is possible to use intermittent lighting programs that intercalate cycles of light and dark, in the period considered as stimulatory of 15 and 16 hours of light, followed by eight and nine hours of continuous dark (FREITAS et al., 2010). Besides allowing the reproductive tract stimulation, intermittent programs reduce feed intake and feed conversion, keeping the eggs' production and weight when compared with continuous ones (FREITAS et al., 2005).

Lineages of modern laying hens are suffering an intense selection pressure for improving the production rates (GEWEHR et al., 2012.), which progressively reduces the sensitivity to the light (TUCKER \& CHARLES, 1993; SAUVEUR, 1996).

Once they are genetically improved for maximum production, changes in the light regime appear in an almost refractory way (TUCKER \& CHARLES, 1993). That causes the need to re-evaluate, periodically, the age for laying hens' photostimulation (ERNST et al., 1987), and it is possible that current lines may be more tolerant to lower light intensities (GEWEHR et al., 2012). In the meantime, there is doubt if the modern lines of high performance still respond to light stimulation (SAUVEUR, 1996).

In this context, the research aims to evaluate the effect of continuous and intermittent light programs with different scotophases on the productive performance and eggs quality of laying hens, applied at the beginning of the laying phase and bred in an open shed.

\section{MATERIALS AND METHODS}

The experiment was performed in the Sector of Poultry of the Department of Animal and Food Production in the Centre of Agroveterinary Sciences of the State Universidade Federal de Santa Catarina, Brazil. 420 Hy-line Brown laying hens were used for six periods of 28 days, bred on wood shaving bedding in an open shed that allows the use of natural photoperiod. The experimental period started when the birds completed 21 weeks old, and at the beginning of the pilot phase $(02 / 10)$ the natural photoperiod contained 13:13h, passing through the winter solstice in the southern region of the country $(06 / 23)$ with $10: 03 \mathrm{~h}$, and at the end of the experiment $(07 / 27)$ the natural photoperiod was of 10:28h (Cotta, 2002). In the growing stage, the birds received continuous and constant lighting program of 13:13h (natural + artificial). At the beginning of the laying phase, the laying hens were subjected to three lighting programs. 1) Continuous Program (PIC) recommended by the breed manual where birds received a continuous $16-\mathrm{h}$ photoperiod (natural + artificial) and a scotoperiod of $8 \mathrm{~h}$. Lamps were lit at $4 \mathrm{am}$ and turned off at $7 \mathrm{am}$, lit again at $5 \mathrm{pm}$ and turned off at $8 \mathrm{pm}$. 2) Intermittent program with two photophases of 15min (PIC15) equidistant from the natural photoperiod. Lamps were lit at $4 \mathrm{pm}$ and closed at 4:15pm (fotophase1) following a scotophase (dark) until dawn, then, it followed with daylight until dusk and dark period (scotophase 2) until 7:45pm. 3) Intermittent program with two photophases of 30min (PIC30) were equidistant from the natural photoperiod. It followed the same principle of the PIC15 and the lamps in the photophases were lit from $4 \mathrm{pm}$ to $4: 30 \mathrm{pm}$ and from $7: 30 \mathrm{pm}$ to $8: 00 \mathrm{pm}$ between the two scotophases and natural light. Time of photophases and scotophases and total light time that the birds received in the intermittent programs, in different periods is shown in table 1 .

The shed was divided into three distinct rooms by using a non-translucent plastic bag to prevent the light passing through from one room to the other. Each room contained ten plots with an area of $2.1 \mathrm{~m}^{2}$ separated by a wire mesh of 1.5 inches, and each parcel equipped with a tubular feeder, two nipple drinkers and three nests $(27 \mathrm{~cm}$ high $\times 27 \mathrm{~cm}$ wide $\times 30 \mathrm{~cm}$ length). Programs lighting control was conducted with the aid of a digital timer, one for each room, with similar size and containing three compact fluorescent lamps of 15 watts each. It was possible to measure, with a light meter, the light intensity of the rooms and none of them showed less than 15 lux at the head height of birds, which were measured at the most equidistant point from lamps. Birds had ad libitum access to food and water, and it was the same diet offered in all lighting programs, composed of corn and soybean meal (Table 2), and formulated according to the nutritional requirements and food composition recommended by ROSTAGNO et al. (2005).

Birds' performance was evaluated by using feed intake $\left(\mathrm{g} \mathrm{bird}^{-1} \mathrm{day}^{-1}\right)$, eggs production $(\%$ eggs bird ${ }^{-1}$ day $^{-1}$ ), feed conversion ( $\mathrm{kg}$ feed kg-1 egg), egg weight $(\mathrm{g})$, mass $(\mathrm{g})$ and density $\left(\mathrm{g} \mathrm{cm}^{-3}\right)$ of eggs, final weight and birds weight gain $(\mathrm{kg})$. Eggs quality was assessed in the last three days of each trial period, where three eggs per day from each experimental repetition were randomly selected for determination of yolk, albumen and peeling (\%), yolk height with and without albumen (mm), yolk diameter with and without albumen $(\mathrm{mm})$ and Haugh unit through the formula $\mathrm{UH}=100 \log \left(\mathrm{H}+7.57-1.7 \mathrm{~W}^{0.37}\right)$, described by EISEN et al. (1962). The experimental design was completely randomized with ten repetitions of 14 birds. Results of global average and each period of 28 days were subjected to the analysis of variance, and the differences were assessed by Tukey test 
Table 1 - Time and month of photophases, natural escotophases and photoperiod according to the age of laying in intermittent programs.

\begin{tabular}{|c|c|c|c|c|c|c|c|c|c|c|}
\hline $\begin{array}{l}\text { Age } \\
\text { (week) }\end{array}$ & $\begin{array}{l}\text { Date } \\
\text { (day/month) }\end{array}$ & $\begin{array}{l}\text { Photopha } \\
\text { s1 (h:m) }\end{array}$ & $\begin{array}{l}\text { Escoto } \\
\text { phase1 } \\
\text { (h:min) }\end{array}$ & $\begin{array}{l}\text { Aurora } \\
\text { (h:mi) }\end{array}$ & $\begin{array}{l}\text { Natural } \\
\text { Light } \\
\text { (h:min) }\end{array}$ & $\begin{array}{l}\text { Sunset } \\
\text { (h:min) }\end{array}$ & $\begin{array}{l}\text { Escotopha } \\
\text { se2 } \\
\text { (h:min) }\end{array}$ & $\begin{array}{l}\text { Photop } \\
\text { hase2 } \\
\text { (h:m) }\end{array}$ & $\begin{array}{l}\text { Scotoperiod } \\
(\mathrm{h}: \mathrm{m})\end{array}$ & $\begin{array}{l}\text { Total } \\
\text { light } \\
\text { (h:min) }\end{array}$ \\
\hline 21 a 24 & $10 / 02$ to $10 / 03$ & $00: 15$ & 02:01 & $06: 16$ & $12: 34$ & $18: 50$ & $00: 55$ & $00: 15$ & 08:00 & $10: 56$ \\
\hline 25 a 28 & $11 / 03$ to $07 / 04$ & $00: 15$ & $02: 21$ & $06: 36$ & $11: 46$ & $18: 22$ & $01: 23$ & $00: 15$ & 08:00 & $11: 44$ \\
\hline 29 a 32 & $08 / 04$ to $05 / 05$ & $00: 15$ & $02: 40$ & $06: 55$ & $10: 54$ & $17: 49$ & $01: 56$ & $00: 15$ & 08:00 & $12: 36$ \\
\hline 33 a 36 & $06 / 05$ to $02 / 06$ & $00: 15$ & $02: 58$ & $07: 13$ & $10: 17$ & $17: 30$ & $02: 15$ & $00: 15$ & 08:00 & $13: 13$ \\
\hline 37 a 40 & $03 / 06$ to $30 / 06$ & $00: 15$ & $03: 10$ & $07: 25$ & $10: 06$ & $17: 31$ & $02: 14$ & $00: 15$ & 08:00 & $13: 24$ \\
\hline 41 a 44 & $01 / 07$ to $27 / 07$ & $00: 15$ & 03:02 & $07: 17$ & $10: 28$ & $17: 45$ & 02:00 & $00: 15$ & 08:00 & $13: 02$ \\
\hline $\begin{array}{l}\text { Age } \\
\text { (week) }\end{array}$ & $\begin{array}{l}\text { Date } \\
\text { (day/month) }\end{array}$ & $\begin{array}{l}\text { Photopha } \\
\text { s1 (h:m) }\end{array}$ & $\begin{array}{l}\text { Escoto } \\
\text { phase1 } \\
\text { (h:min) }\end{array}$ & $\begin{array}{l}\text { Aurora } \\
\text { (h:mi) }\end{array}$ & $\begin{array}{l}\text { Natural } \\
\text { Light } \\
\text { (h:min) }\end{array}$ & $\begin{array}{l}\text { Sunset } \\
\text { (h:min) }\end{array}$ & $\begin{array}{l}\text { Escotopha } \\
\text { se2 } \\
\text { (h:min) }\end{array}$ & $\begin{array}{l}\text { Photop } \\
\text { hase2 } \\
\text { (h:m) }\end{array}$ & $\begin{array}{l}\text { Scotoperiod } \\
\text { (h:m) }\end{array}$ & $\begin{array}{l}\text { Total } \\
\text { light } \\
\text { (h:min) }\end{array}$ \\
\hline 21 a 24 & $10 / 02$ to $10 / 03$ & $00: 30$ & $01: 46$ & $06: 16$ & $12: 34$ & $18: 50$ & $00: 40$ & $00: 30$ & 08:00 & $10: 26$ \\
\hline 25 a 28 & $11 / 03$ to $07 / 04$ & $00: 30$ & 02:06 & $06: 36$ & $11: 46$ & $18: 22$ & 01:08 & $00: 30$ & 08:00 & $11: 14$ \\
\hline 29 a 32 & $08 / 04$ to $05 / 05$ & $00: 30$ & $02: 25$ & $06: 55$ & $10: 54$ & $17: 49$ & 01:41 & $00: 30$ & 08:00 & $12: 06$ \\
\hline 33 a 36 & $06 / 05$ to $02 / 06$ & $00: 30$ & $02: 43$ & $07: 13$ & $10: 17$ & $17: 30$ & $02: 15$ & $00: 30$ & 08:00 & $12: 43$ \\
\hline 37 a 40 & $03 / 06$ to $30 / 06$ & $00: 30$ & $02: 55$ & $07: 25$ & $10: 06$ & $17: 31$ & 01:59 & $00: 30$ & 08:00 & $12: 54$ \\
\hline 41 a 44 & $01 / 07$ to $27 / 07$ & $00: 30$ & $02: 47$ & $07: 17$ & $10: 28$ & $17: 45$ & $01: 45$ & $00: 30$ & 08:00 & $12: 32$ \\
\hline
\end{tabular}

*Intermittent lighting program with photophases $15 \mathrm{~min}$.

** Intermittent lighting program with photophases $30 \mathrm{~min}$.

(5\%) through the procedure PROC GLM of the computational software $\mathrm{SAS}^{\circledR}$ (2009).

\section{RESULTS AND DISCUSSION}

The effect $(\mathrm{P}<0.05)$ of lighting programs occurred on the feed intake (Table 3 ) in the overall average of all experimental periods. In PII15, the birds had a lower intake $(\mathrm{P}<0.05)$ about the PIC estimated at $2.5 \%$ of reduction. Meanwhile, the consumption was similar $(\mathrm{P}>0.05)$ between PIC and PII30, and between PII30 and PII15. The consumption reduction in intermittent programs about the continuous ones is also described in other works (FREITAS et al., 2005; KOELKEBECK \& BIELLIER, 1986), attributing it to birds reduction in the execution of primary activities (locomotion). Consequently, there was a decline in feed intake (COENEN et al., 1988). Since the trial period proceeded in a decreasing natural photoperiod, and therefore, with a gradual increase of scotophases, it was observed that only in the last period, 41-44 weeks (Figure 1), there was a consumption difference $(\mathrm{P}<0.05)$ between programs. Thus, the difference found in the global average of feed intake had a direct influence of that period, which coincided with the winter solstice, when the scotophases of intermittent programs were larger and when the natural photoperiod was the lowest throughout the year (10: 06h).

Eggs production (Table 3 ) was higher $(\mathrm{P}<0.05)$ in the PIC program $(93.2 \%)$ compared to the programs PII15 (91.5\%) and PII30 (91.6\%) during the trial period, and the intermittent programs showed similar results $(\mathrm{P}>0.05)$. Reduction in intermittent programs production was around $1.8 \%$ in a total period of 24 evaluated weeks, indicating that intermittent programs of 15 and $30 \mathrm{~min}$ did not stimulate the reproductive tract to its maximum productivity. Nevertheless, that little numerical difference observed, along with a high cost of electricity, can be taken into account by the producers, in the practice.

Probably, the increase of scotophases compromises the release of GnRH. When birds are exposed to a shorter time of light, it reduces the hormone release, which in turn reduces the release of gonadotropins. Then, it does not stimulate growth and follicular maturation jeopardizing the eggs production (SHARP, 1993).

The results obtained in the experiment about eggs production corroborates those achieved by KOELKEBECK \& BIELLIER (1986) in testing 
Table 2 - Calculated composition of experimental diet.

\begin{tabular}{|c|c|}
\hline Ingredients & $\%$ \\
\hline Corn & 59.20 \\
\hline Soybean meal & 27.50 \\
\hline Limestone & 9.65 \\
\hline Dicalcium phosphate & 1.30 \\
\hline Methionine & 0.15 \\
\hline Salt & 0.30 \\
\hline Vegetable oil & 1.40 \\
\hline Vitamin and supplement mineral $^{1}$ & 0.30 \\
\hline Adsorbent & 0.20 \\
\hline Total & 100.0 \\
\hline \multirow{2}{*}{\multicolumn{2}{|c|}{ Metabolizable energy $\left(\mathrm{Kcal} \mathrm{kg}^{-1}\right) \quad 2.745$}} \\
\hline & \\
\hline Crude protein $(\%)$ & 17.0 \\
\hline Calcium $(\%)$ & 4.2 \\
\hline Phosphorus (\%) & 0.375 \\
\hline Methionine (\%) & 0.408 \\
\hline Lysine (\%) & 0.811 \\
\hline
\end{tabular}

${ }^{1}$ Vitamin and mineral supplement containing per kg: Vit. A 2.333.330IU Vit. D3 - 666 670IU Vit. E - 1666670. Vit. K3 533330 . Vit. B2 - $1.000 \mathrm{mg}$. Vit. B12 - $2666670 \mathrm{mg}$. Niacin $6666670 \mathrm{mg}$. Hill - 78.120mg. BC. Pantothenic - $1166670 \mathrm{mg}$ Copper - 2.666.700mg. Iron - 16.670g. Manganese - 23.330g. Zinc - 16.670g. Iodine - 400mg. Selenium 66.670mg. Zinc Bacitracin - 6666670mg.

intermittent programs applied at 21 weeks of age. Analyzing the production of eggs in each period it was observed (Figure 1) that birds which received intermittent programs had lower production only in the last two periods, coinciding with the time in which they were exposed to a shorter natural light.

Analyzing the production of eggs in each period it was possible to observe (Figure 1) that birds which received intermittent programs had lower production only in the last two periods, coinciding with the time in which they were exposed to a shorter natural light. Feed conversion (Table 3) was not altered $(\mathrm{P}>0.05)$ between the lighting programs, indicating that the birds under continuous treatment, although they consumed more food that the birds of PII15 treatment, produced more eggs providing an equal feed conversion. A similar result was obtained in the study performed by KOELKEBECK et al., (1986). In contrast, SAUVEUR \& MONGIN (1983), FREITAS et al. (2005), GEWEHR et al. (2012) reported that intermittent programs reduced feed conversion about ongoing programs. However, these studies were performed with birds previously trained with continuous photoperiod and applied after 40 weeks of age.

Eggs mass (Table 3) showed differences $(\mathrm{P}<0.05)$ only between the PIC and PII15, and it was lower $(\mathrm{P}<0.05)$ in the intermittent one. The mass is a relation between eggs production and weight, and although the eggs weight (Table 3) was not altered $(\mathrm{P}>0.05)$, the birds subjected to continuous light presented an increased production, which directly reflected in the mass result. The results reported here are contrary to those reported by BANKS \& KOEN (1989) and FREITAS et al. (2005), which reported

Table 3 - Performance and quality of laying hens eggs subjected to continuous and intermittent lighting programs 21-45 weeks old in decreasing natural photoperiod.

\begin{tabular}{|c|c|c|c|c|c|}
\hline \multirow{2}{*}{ Performance } & \multicolumn{3}{|c|}{ 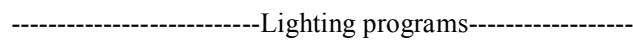 } & \multirow{2}{*}{$\mathrm{CV}(\%)^{*}$} & \multirow{2}{*}{$\mathrm{P}$ value } \\
\hline & $\mathrm{PIC}^{1}$ & $\mathrm{PII}^{3} 5^{3}$ & PII $30^{2}$ & & \\
\hline Fed intake $\left(\mathrm{g} \mathrm{bird}^{-1}\right.$ day $\left.^{-1}\right)$ & $119.5 \mathrm{~A}$ & $116.5 \mathrm{~B}$ & $117.3 \mathrm{AB}$ & 5.87 & 0.04 \\
\hline Egg production $(\%)$ & $93.2 \mathrm{~A}$ & $91.5 \mathrm{~B}$ & $91.6 \mathrm{~B}$ & 3.81 & 0.01 \\
\hline Egg weight (g) & 63.7 & 63.1 & 63.1 & 4.16 & 0.33 \\
\hline Food conversion $\left(\mathrm{kg} \mathrm{kg}^{-1}\right)$ & 1.87 & 1.84 & 1.86 & 4.00 & 0.09 \\
\hline Egg mass $(g)$ & $59.5 \mathrm{~A}$ & $57.7 \mathrm{~B}$ & $57.8 \mathrm{AB}$ & 6.99 & 0.03 \\
\hline Final weight $(\mathrm{kg})$ & 2.12 & 2.09 & 2.09 & 2.35 & 0.41 \\
\hline Weight gain $(\mathrm{kg})$ & 0.39 & 0.37 & 0.37 & 11.16 & 0.44 \\
\hline Density $\left(\mathrm{g} \mathrm{cm}^{-3}\right)$ & 1089 & $\begin{array}{l}\text { gg qualit } \\
1089\end{array}$ & 1089 & 0.25 & 0.55 \\
\hline Haugh Unit & 97.3 & 98.2 & 98.6 & 2.69 & 0.52 \\
\hline Albumen height (mm) & 9.84 & 10.1 & 10.1 & 5.79 & 0.63 \\
\hline Yolk (\%) & 23.6 & 23.5 & 23.9 & 3.44 & 0.44 \\
\hline Shell (\%) & 9.71 & 9.85 & 9.77 & 3.05 & 0.59 \\
\hline Albumen (\%) & 66.7 & 66.7 & 66.2 & 1.50 & 0.59 \\
\hline
\end{tabular}

Followed overall averages of unequal letters on the lines differ statistically by Tukey test $(5 \%) .{ }^{*} \mathrm{CV}$ : Coefficient of variation.

${ }^{1}$ PIC: Ongoing program; ${ }^{2}$ PII30: Intermittent Program with photoperiod of 30min; ${ }^{3}$ PII 15 : Intermittent Program with photoperiod of $15 \mathrm{~min}$.

Ciência Rural, v.46, n.11, nov, 2016. 

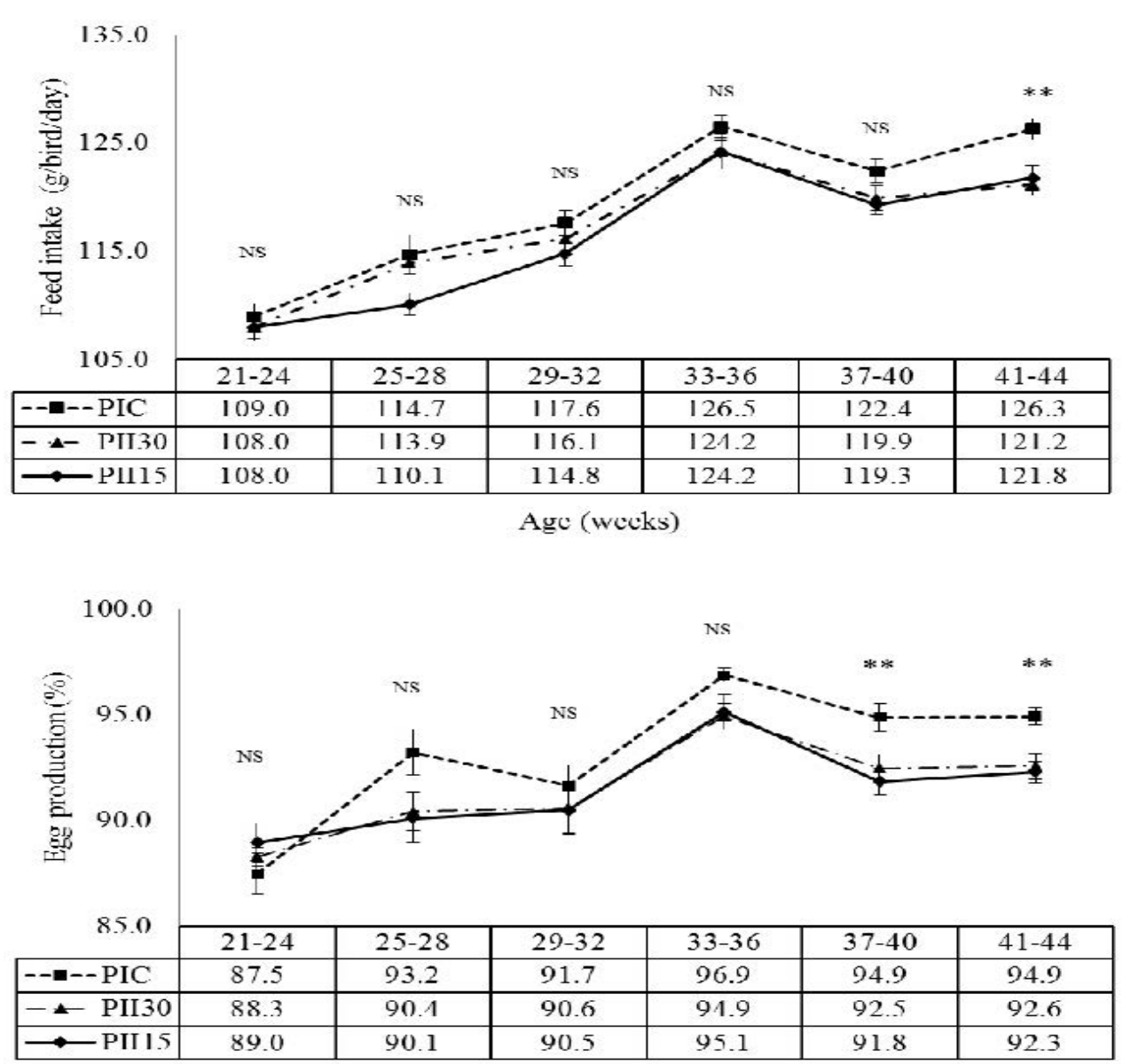

Age (weeks)

Figure 1 - Feed intake and production of laying eggs subjected to lighting programs 21-45 weeks old in decreasing natural photoperiod. PIC: Continuous program; PII30: Intermittent program with photoperiod of 30min; PII15: Intermittent Program with photoperiod of $15 \mathrm{~min}$.

no differences between the intermittent and continuous photoperiod. However, these studies were carried out with birds older than 45 weeks of age; and therefore, they had been previously trained to a continuous photoperiod. The egg mass differed between the programs in four of the six periods analyzed (Figure 2). The result reflects the higher production of eggs observed in the continuous program in relation to the intermittent one, and it is lower in intermittent programs when approaching to the winter solstice, i.e. it is influenced by the scotophases.

The final weight and weight gain of the birds were not affected $(\mathrm{P}>0.05)$, in different lighting programs. The highest feed intake observed in the PIC program did not reflect greater weight in the birds, which indicates that it was used for the bigger nutritional requirement of eggs production fr eported in that program related to the intermittent ones. The eggs quality (Table 3) did not change due to lighting programs. The high P-value (probability) coupled with the low coefficient of variation obtained in the observation of variables to certify the eggs quality (Table 3) is an excellent indication that the intermittent lighting programs do not affect the eggs quality. KOELKEBECK et al. (1986) also indicated that eggs density and Haugh unit were not affected when comparing the continuous and intermittent programs applied from 21 weeks of age.

\section{CONCLUSION}

The use of intermittent programs for semiheavy laying hens bred on bedding in an open shed, applied at the beginning of the laying phase, reduces 


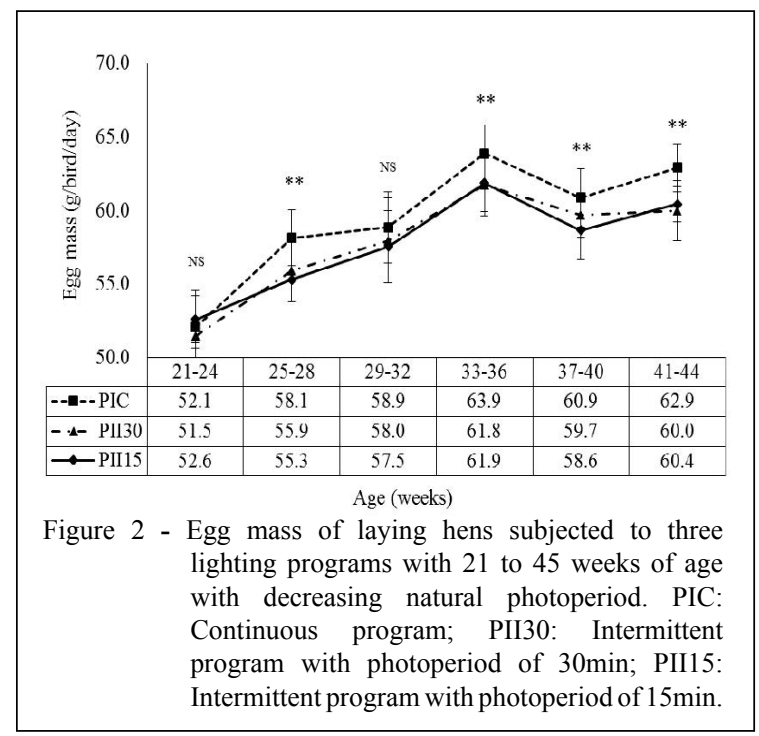

their productive performance during the winter solstice without affecting the eggs quality.

\section{BIOETHICS AND BIOSSECURITY COMMITTEE APPROVAL}

The experimental procedures used in this study were approved by the Ethics Committee for Animal Experimentation of Centre of Agroveterinary Sciences of the Universidade Federal de Santa Catarina State under the $\mathrm{n}^{\circ} 1.66 .12$ protocol.

\section{REFERENCES}

BANKS, P.A.; KOEN, T.B. Intermittent lighting regimens for laying hens. Poultry Science, v.68, n.6, p.739-743, 1989. Available from: $<$ http://ps.oxfordjournals.org/content/68/6/739.full.pdf + html $>$. Accessed: Nov. 20, 2015. doi: 10.3382/ps.0680739.

COENEN, A.M.L. Effects of intermittent lighting on sleep and activity in the domestic hen. Applied Animal Behaviour Science, v.20, n.3-4, p.309-318, 1988. Available from: <http:// www.sciencedirect.com/science/article/pii/016815918890055X $>$. Accessed: Nov. 20, 2015. doi: 10.1016/0168-1591(88)90055-X.

COTTA, J.T. de B. Galinha: produção de ovos. Viçosa: Aprenda Fácil, 2002. 191p.

EISEN, E.J. et al. The haugh unit as a measure of egg albumen quality. Poultry Science, v.41, n.1937, p.1461-1468, 1962. Available from: <http://ps.oxfordjournals.org/content/41/5/1461. full.pdf + html $016815918890055 \mathrm{X}>$. Accessed: Nov. 22, 2015. doi: $10.3382 / \mathrm{ps} .0411461$

ER, D. et al. Effect of monochromatic light on the egg quality of laying hens. Journal of Applied Poultry Research, v.16, p.605-612, 2007. Available from: <http://japr.oxfordjournals. org/content/16/4/605.abstract>. Accessed: Nov. 22, 2015. doi: 10.3382/japr.2006-00096.
ERNST, R.A. et al. Review of life-history lighting programs for commercial laying fowls. World's Poultry Science Journal, v.43, p.44-55, 1987. Available from: <http://journals.cambridge. org/action $/$ displayAbstract? fromPage $=$ online $\&$ aid $=958300>$. Accessed: Nov. 22, 2015. doi: 10.1079/WPS19870005.

FREITAS, H.J. de et al. Evaluation of lightning programs upon the performance of white egg layers. Ciência e Agrotecnologia, v.29, n.2, p.424-428, 2005. Available from: <http://www.scielo.br/ pdf/cagro/v29n2/a21.pdf>. Accessed: Nov. 22, 2015. doi: 10.1590/ S1413-70542005000200021.

FREITAS, H.J. de et al. Efeito de diferentes programas de iluminação para poedeiras semi-pesadas criadas em galpões abertos. Resumo. Biotemas, v.23, n.2, p.157-162, 2010. Available from: <https://periodicos.ufsc.br/index.php/biotemas/article/ view/2175-7925.2010v23n2p157>. Accessed: Dez. 02, 2015. doi: $10.5007 / 2175-7925.2010 \mathrm{v} 23 \mathrm{n} 2 \mathrm{p} 157$.

GEWEHR, C.E.; FREITAS, H.J. Intermittent lighting for layer hens rearing in open shelters. Revista de Ciências Agroveterinárias, v.6, n.1, p.54-62, 2007. Available from: $<$ http://rca.cav.udesc.br/rca_2007_1/gewehr.pdf $>$. Accessed: Dez. 02, 2015.

GEWEHR, C.E. et al. Programas de iluminação para poedeiras semi-pesadas. Biotemas, v.25, n.1, p.151-157, 2012. Available from: <https://periodicos.ufsc.br/index.php/biotemas/article/ view/2175-7925.2012v25n1p151>. Accessed: Dez. 02, 2015. doi: $10.5007 / 2175-7925.2012 \mathrm{v} 25 \mathrm{n} 1 \mathrm{p} 151$.

KOELKEBECK, K.W.; BIELLIER, H.V. Ahemeral light-dark cycles and intermittent photoperiod effects on laying hens. Poultry Science, v.65, n.11, p.2002-2007, 1986. Available from: <http:// ps.oxfordjournals.org/content/65/11/2002.long>. Accessed: Dez. 02, 2015. doi: 10.3382/ps.0652002.

ROSTAGNO, H.S. et al. Tabelas brasileiras para aves e suínos: composição de alimentos e exigências nutricionais. 2.ed. Viçosa: UFV/DZO, 2005. 186p.

SAUVEUR, B. Photopériodisme et reproduction des oiseaux domestiques femelles. Production Animal, v.9, n.1, p.25-34, 1996. Available from: <https://www6.inra.fr/productionsanimales/1996-Volume-9/Numero-1-1996/Photoperiodisme-etreproduction-des-oiseaux-domestiques-femelles $>$. Accessed: Dez. 02, 2015.

SAUVEUR, B.; MONGIN, P. Performance of layers reared and/or kept under different 6-hour light-dark cycles. British Poultry Science, v.24, n.3, p.405-416, 1983. Available from: <http://www.tandfonline.com/doi/ abs/10.1080/00071668308416755>. Accessed: Dez. 05, 2015. doi: $10.1080 / 00071668308416755$.

SHARP, P.J. Photoperiodic control of reproduction in the domestic hen. Poultry Science, v.72, n.5, p.897-905, 1993. Available from: $<$ http://ps.oxfordjournals.org/content/72/5/897.long $>$. Accessed: Dez. 05, 2015. doi: 10.3382/ps.0720897.

TUCKER, S.A.; CHARLES, D.R. Light intensity, intermittet lighting and feeding regime during rearing as affecting egg production and egg quality. British Poultry Science, v.34, n.2, p.255-266, 1993. Available from: <http://www.tandfonline.com/ doi/abs/10.1080/00071669308417582>. Accessed: Dez. 05, 2015. doi: $10.1080 / 00071669308417582$. 